\title{
Large intraspinal cement leak during multilevel cement-augmented screw fixation
}

\author{
Mantu Jain (ㄷ, ${ }^{1}$ Manmatha Nayak, ${ }^{1}$ Auroshish Sahoo, ${ }^{1}$ Nitasha Mishra Mishra ${ }^{2}$
}

${ }^{1}$ Orthopaedics, All India Institute of Medical Sciences Bhubaneswar, Bhubaneswar, India

${ }^{2}$ Anaesthesia, All India Institute of Medical Sciences Bhubaneswar, Bhubaneswar, India

\section{Correspondence to}

Dr Mantu Jain;

montu_jn@yahoo.com

Accepted 28 November 2021

Check for updates

(C) BMJ Publishing Group Limited 2021. No commercial re-use. See rights and permissions. Published by BMJ.

To cite: Jain M, Nayak M, Sahoo A, et al. BMJ Case Rep 2021;14:e247466. doi:10.1136/bcr-2021247466

\section{DESCRIPTION}

Cement augmentation of pedicle screws effectively provides adequate anchorage in an osteoporotic spine as it increases the pedicle screw interface and pull-out strength. ${ }^{1}$ However, there are potential dangers of cement leak (CL) in $11.2 \%-82.4 \%$ of patients. ${ }^{2}$ These leaks are intradiscal or extravertebral when they can be asymptomatic, but rarely can there be an intraspinal leak. Even though rare, the leakage of cement into the spinal canal can have devastating consequences. ${ }^{3}$ The resulting neurological injury becomes permanent if there is thermal or chemical burn by the cement. ${ }^{4}$ Mechanical compression is also theoretically possible. This complication's standard assessment and management are not very clearly defined, as many cases may be under-reported. We describe long intraspinal CL in patients with L1 burst fracture, which spared the spinal cord through immediate decompression. The purpose is to sensitise the readers about this scary complication which can be overwhelming for both the patient and the surgeon.

\section{Case}

A 62-year-old woman was admitted with severe back pain following a slip of step at home for 2 weeks. She was able to walk with a frame before admission. She denied any fever or constitutional symptoms. She had attained menopause 8 years ago. On examination, she had a local tenderness over L1 with difficulty in turning. Neurological examination revealed the weakness of hip flexion and knee extensor $4 / 5$ bilaterally. Sensory was also diminished one-half in the L2-4 dermatome. Bowel and bladder were preserved. The blood count was normal, including haemoglobin level, white cell count, platelet count, erythrocyte sedimentation rate and serum electrophoresis. Radiographs of the lumbosacral spine showed osteoporosis features with diffuse osteopenia, multiple level collapse and fulcrum at L1 on loading (sitting) film (figure 1A). An MRI revealed a fresh fracture at L1 (hyper T2 and Short tau inversion recovery images) with old healed osteoporotic fractures (figure 1B). The CT also confirmed the same without any intervertebral gas shadow, ruling out Kummel's lesion (figure 1C). A Dual-energy X-ray absorptiomerty scan for bone mineral density (BMD) revealed a score of -4.3 . The patient was started on teriparatide $20 \mu \mathrm{g} / \mathrm{day}$, and screening for malignancy was done, including an ultrasound of the abdomen and pelvis, breast examination and CT of the thorax, which were all negative. After 3 weeks, she was planned for posterior fixation and anterior reconstruction through the posterior approach.
Under general anaesthesia, the patient was placed prone, and midline exposure was done. The pedicle (two up and down) was probed, and the fenestrated screw (GESCO India, having three pairs of holes at 1800) was applied. The consistency of bone was like butter. Cement augmentation was done (when consistency was 'toothpaste-like') putting the device in all eight screws simultaneously with $2 \mathrm{~mL}$ cement (Vebroplast, Leader Biomedical). The surgeon and assistant gently guided the cement in the screw. An intraoperative fluoroscopy picture showed a doubtful CL on the left side that travelled linearly to the segment above instrumentation. Immediate hemilaminectomy of the superior segments was done while the anaesthetist prepared for the wake-up test. A probe was used to feel the cement, but a posterior longitudinal ligament was felt. The patient was moving bilateral limbs in a wake-up call. The anaesthesia was deepened once again and L1 corpectomy was completed as planned from the posterior aspect, and a cage with bone graft was applied. The rods were inserted. The wound was closed in layers. A postoperative radiograph and CT scan confirmed the linear CL on the left side, which was asymptomatic (figure 2A-C). The procedure was explained to the patient's party and the patient was subsequently discharged with osteoporotic medical therapy.

More aged people require spine fixation, and the challenge is on osteoporotic spine. The cementaugmented pedicle screw instrumentation is now widely used in these populations, and studies have shown to provide reliable biomechanical stability. ${ }^{5-7}$ But the treatment carries an inherent risk of CL which, fortunately, in most cases, is asymptomatic but can be catastrophic.

Mueller et al evaluated 98 patients and found $73.3 \%$ perivertebral CL in their series. CL most often occurs in the venous system, including epidural veins via the basivertebral veins. ${ }^{7}$ Hence, they had no neurological deterioration, and cement removal was not required. In our case, we also found a linear $\mathrm{CL}$ along the epidural vein without any devastating complication. Yeom et al had found 28 leaks into the spinal canal, occupying less than one-third of the canal and without neurological consequences. The authors attributed this to the venous engulfment of cement. ${ }^{8}$ They also described three patterns of leakage. Type B pattern is in the basivertebral vein, type $\mathrm{S}$ in the segmental vein and type $\mathrm{C}$ is due to a cortical breach. Type B leaks involve intrusion into the spinal canal that can spread along the epidural venous plexus, as seen in our case. However, such a long spread to two adjacent segments has not 


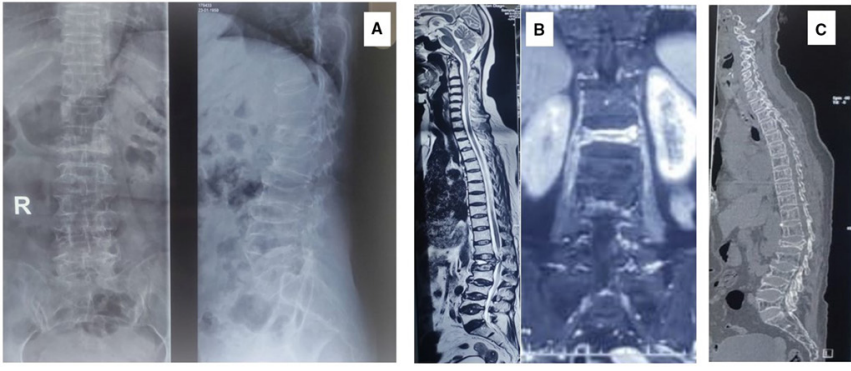

Figure 1 (A) X-ray anteroposterior and lateral views show multiple osteoporotic fractures; (B) MRI T2-weighted confirms the L1 fracture which was enhanced from the Short tau inversion recovery image; (C) CT scans exclude any intrabody gas or cleft.

been described before. It is important to differentiate here from type $\mathrm{C}$ leaks due to cortical breach that can also intrude in the spinal canal. However, such a situation will produce a localised mass depending on the amount of extruded cement. There is also a correlation between the volume of cement injected and the possibility of CL. ${ }^{5}$ Biomechanically, the strength of screws does not increase with greater than $2.8 \mathrm{~mL}$ cement per pedicle. ${ }^{9}$ Some authors have described cement volume to be one-fourth of the vertebral body fraction for optimal results. ${ }^{10}$ Other factors attributing to CL include the pressure of injection, the consistency of cement at the time of application, the venous system's anatomy and multilevel fixation. ${ }^{1}$ The venous plexus is devoid of any valves, and the pressure in the lower vertebral spongiosa makes them suitable for leaks. In one study, Kaso et al found that the medially placed needle had more basivertebral leak than a lateral position. ${ }^{11}$ We find that our left screw was more medially placed on careful examination than the right side, which could have triggered a leak on the left side. Schmoelz et al advocate using cement in 'toothpaste' consistency. ${ }^{12}$ Arabmotlagh et $a l$ and Tang $e t ~ a l^{1}$ advocate for less cement and less number of screws in multilevel fixation. ${ }^{13}$

The fenestrated holes and screw tips give way for the cement. In a study, Guo et al found that a smaller distance from the tip of the screw to the vertebral body midline was associated with a higher risk of a leak. ${ }^{14} \mathrm{Hu}$ et al found that patients with low BMD $(<0.6 \mathrm{~g} / \mathrm{cm})$ had more CL risk and had somewhat scattered than concentrated distribution of cement around screws. ${ }^{15}$ Paré et al compared fenestrated screws with conventional screws. The fenestrated screws fare better as far as CL
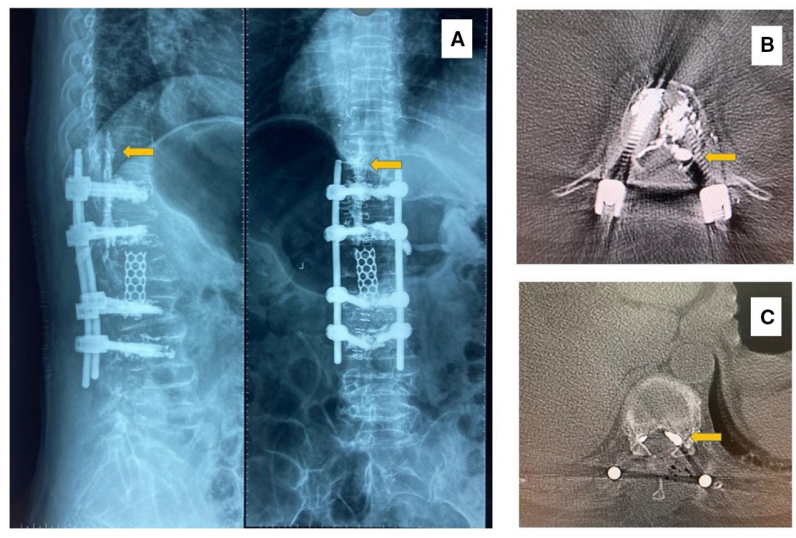

Figure 2 (A) Postoperative X-ray shows a cement leakage ascending vertically up to D10 level. The CT axial scans confirm laminectomy in (B), and type $B$ leak in $(B, C)$. is concerned. ${ }^{16} \mathrm{Kim}$ et al also found that cement instillation through fenestrated screws was more effective than solid screw insertion after prefilling of polymethyl methacrylate with vertebroplasty. ${ }^{17}$ Liu et al studied four holes versus six holes in fenestrated screws and found the former as an optimal cement augmentation. ${ }^{18}$ Immediate cement removal following decompression is a matter of debate as most are innocent leaks, but neurological deterioration is reported. ${ }^{3}$ Hence, the surgeon needs to be alert on radiological imaging during the procedure for any prompt action.

\section{Learning points}

- Cement leak is a potential threat in cement-augmented pedicle screws used in osteoporotic spine more so in multilevel fixation.

- A 'type B' leak which occupies less than one-third of spinal canal and is linear along the epidural vein is usually dormant.

- Cementation through fenestrated screws is more effective than solid screws with prior cementation; however, the volume of polymethyl methacrylate should be between 1.5 and $2 \mathrm{~mL}$ with a careful manual injection to prevent any inadvertent leak.

Contributors MJ, MN and AS were chief operating surgeons, whereas NMM was the anaesthetist. AS got the CT scan done and was responsible for follow-up. MJ and MN wrote up the paper, whereas NMM and AS gave critical inputs. All authors have read and agree with the content of the manuscript.

Funding The authors have not declared a specific grant for this research from any funding agency in the public, commercial or not-for-profit sectors.

Competing interests None declared.

Patient consent for publication Obtained.

Provenance and peer review Not commissioned; externally peer reviewed.

Case reports provide a valuable learning resource for the scientific community and can indicate areas of interest for future research. They should not be used in isolation to guide treatment choices or public health policy.

ORCID iD

Mantu Jain http://orcid.org/0000-0003-3848-4277

\section{REFERENCES}

1 Tang Y-C, Guo H-Z, Guo D-Q, et al. Effect and potential risks of using multilevel cement-augmented pedicle screw fixation in osteoporotic spine with lumbar degenerative disease. BMC Musculoskelet Disord 2020;21:1-12.

2 Martín-Fernández M, López-Herradón A, Piñera AR, et al. Potential risks of using cement-augmented screws for spinal fusion in patients with low bone quality. Spine J 2017;17:1192-9.

3 Nussbaum DA, Gailloud P, Murphy K. A review of complications associated with vertebroplasty and kyphoplasty as reported to the food and drug administration medical device related web site. J Vasc Interv Radiol 2004;15:1185-92.

4 Teng MMH, Cheng H, Ho DM-T, et al. Intraspinal leakage of bone cement after vertebroplasty: a report of 3 cases. AJNR Am J Neuroradiol 2006;27:224-9.

5 Amendola L, Gasbarrini A, Fosco M, et al. Fenestrated pedicle screws for cementaugmented purchase in patients with bone softening: a review of 21 cases. $J$ Orthop Traumatol 2011;12:193-9.

6 Rong Z, Zhang F, Xiao J, et al. Application of Cement-Injectable cannulated pedicle screw in treatment of osteoporotic thoracolumbar vertebral compression fracture (AO type A): a retrospective study of 28 cases. World Neurosurg 2018;120:e247-58.

7 Mueller JU, Baldauf J, Marx S, et al. Cement leakage in pedicle screw augmentation: a prospective analysis of 98 patients and 474 augmented pedicle screws. J Neurosurg Spine 2016;25:103-9.

8 Yeom JS, Kim WJ, Choy WS, et al. Leakage of cement in percutaneous transpedicular vertebroplasty for painful osteoporotic compression fractures. J Bone Joint Surg $\mathrm{Br}$ 2003;85:83-9

9 Fölsch C, Goost H, Figiel J, et al. Correlation of pull-out strength of cementaugmented pedicle screws with CT-volumetric measurement of cement. Biomed Tech 2012;57:473-80 
10 Nieuwenhuijse MJ, Bollen L, van Erkel AR, et al. Optimal intravertebral cement volume in percutaneous vertebroplasty for painful osteoporotic vertebral compression fractures. Spine 2012;37:1747-55.

11 Kasó G, Horváth Z, Szenohradszky K, et al. Comparison of CT characteristics of extravertebral cement leakages after vertebroplasty performed by different navigation and injection techniques. Acta Neurochir 2008;150:677-83.

12 Schmoelz W, Heinrichs CH, Schmidt S, et al. Timing of PMMA cement application for pedicle screw augmentation affects screw anchorage. Eur Spine J 2017:26:2883-90.

13 Arabmotlagh M, Rickert M, Lukas A, et al. Small cavity creation in the vertebral body reduces the rate of cement leakage during vertebroplasty. J Orthop Res 2017:35:154-9.

14 Guo H-Z, Tang Y-C, Guo D-Q, et al. The cement leakage in cement-augmented pedicle screw instrumentation in degenerative lumbosacral diseases: a retrospective analysis of 202 cases and 950 augmented pedicle screws. Eur Spine J 2019;28:1661-9.
$15 \mathrm{Hu}$ M-H, Wu HTH, Chang M-C, et al. Polymethylmethacrylate augmentation of the pedicle screw: the cement distribution in the vertebral body. Eur Spine J 2011:20:1281-8.

16 Paré PE, Chappuis JL, Rampersaud R, et al. Biomechanical evaluation of a novel fenestrated pedicle screw augmented with bone cement in osteoporotic spines. Spine 2011;36:E1210-4.

$17 \mathrm{Kim} \mathrm{JH}$, Ahn DK, Shin WS, et al. Clinical effects and complications of pedicle screw augmentation with bone cement: comparison of fenestrated screw augmentation and vertebroplasty augmentation. Clin Orthop Surg 2020;12:194-9.

18 Liu D, Sheng J, Wu H-H, et al. Biomechanical study of injectable hollow pedicle screws for PMMA augmentation in severely osteoporotic lumbar vertebrae: effect of PMMA distribution and volume on screw stability. J Neurosurg Spine 2018;29:639-46.

Copyright 2021 BMJ Publishing Group. All rights reserved. For permission to reuse any of this content visit https://www.bmj.com/company/products-services/rights-and-licensing/permissions/

BMJ Case Report Fellows may re-use this article for personal use and teaching without any further permission.

Become a Fellow of BMJ Case Reports today and you can:

- Submit as many cases as you like

Enjoy fast sympathetic peer review and rapid publication of accepted articles

- Access all the published articles

Re-use any of the published material for personal use and teaching without further permission

Customer Service

If you have any further queries about your subscription, please contact our customer services team on +44 (0) 2071111105 or via email at support@bmj.com.

Visit casereports.bmj.com for more articles like this and to become a Fellow 